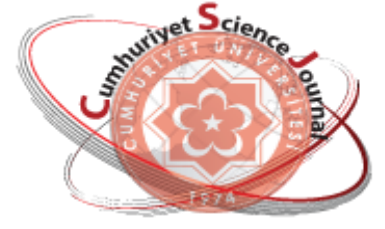

e-ISSN: $2587-246 X$

ISSN: 2587-2680

\section{Cumburiyot Seionee Journal}

esj

Cumhuriyet Sci. J., Vol.40-1(2019) 213-220

\title{
Design of Reversed-Phase Chromatography Column Packing Material for Protein Separation: Part 2- Chromatographic Performance
}

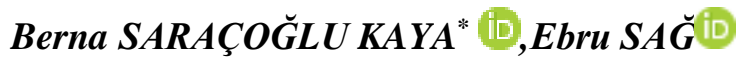 \\ Sivas Cumhuriyet University, Faculty of Engineering, Chemical Engineering Department, Sivas, TURKEY \\ Received: 11.12.2017; Accepted: 13.11.2018 \\ http://dx.doi.org/10.17776/csj.364625
}

\begin{abstract}
In the second part of the two-part study, monodisperse and porous poly(vinyl acetate-codivinylbenzene) [poly(VAc-co-DVB)] and poly(divinylbenzene) [poly(DVB)] column packing materials synthesized in the first part of the study were tested in Reverse Phase Chromatography (RPC) under different conditions. The investigation of column performances concluded that columns packed with poly(VAc-coDVB) (2500 plate/m) and poly(DVB) (1500 plate/m), showed high and stable theoretical plate number and high peak resolution values compared to literature values. Protein recovery data in RPC column, poly(VAcco-DVB) (93-99\%), were determined as similar as quantitative values for all proteins. Reproducibility tests of analytes of poly(VAc-co-DVB) column were assessed "run to run" and "day to day" Relative Standard Deviation (RSD) values were determined under $2.8 \%$.
\end{abstract}

Keywords: Monodisperse-Porous Particle, Column Packed Material, Reversed-Phase Chromatography (RPC), Protein Separation.

\section{Proteinleri Ayırmak İçin Ters Faz Kromatografisi Kolon Dolgu Materyali Tasarımı: Bölüm 2- Kromatografik Performans}

\begin{abstract}
Özet. İki bölümden oluşan çalışmanın ikinci bölümünde çalışmanın ilk bölümünde sentezlenmiş olan eş boyutlu ve gözenekli poli(vinil asetat-co-divinilbenzen) [poli(VAc-co-DVB)] ve poli(divinilbenzen) [poli(DVB)] kolon dolgu materyalleri Ters Faz Kromatografisi (Reversed Phase Chromatography, RPC) için farklı koşullarda test edilmiştir. Sentez sonrası elde edilen partiküllerle doldurulan kolonların kromatografik performansları incelediğinde, poli(VAc-co-DVB) (2500 tabaka/m) ve poli(DVB) (1500 tabaka/m) kolon için literatürdeki değerlerden daha yüksek ve kararlı teorik tabaka sayısı değerleri elde edilirken pik çözünürlük değerlerinin de kabul edilen değerlerin üstünde olduğu görülmüştür. Poli(VAc-co-DVB) (\%93-99) ulaşılan protein geri kazanım değerleri ise bütün proteinler için kantitatife yakın değerler olarak belirlenmiştir. Üretilen kolonlar için analitlerin, analizden analize ve günden güne tekrarlanabilirlik testleri yapılmış, hem "analizden analize " hem de "günden güne" Bağıl Standart Sapma (BSS) değerleri \% 2,8'in altında bulunmuştur.
\end{abstract}

Anahtar Kelimeler: Eşboyutlu-Gözenekli Partikül, Kolon Dolgu Materyali, Ters Faz Kromatografisi (RPC), Protein Ayırma.

\section{INTRODUCTION}

Chromatography, one of the most common analytical techniques used today, began to be used as separation technology in the 20th century [1-9]. Chromatograph is a separation method based on the differential migration of analytes in a mobile phase as they move along a stationary phase. The diversity and development of the technique used have led to the discovery of various principles, the 
expansion of the target and application areas of the technique [10]. Chromatography types can be categorized as Partition Chromatography, Paper Chromatography, Thin Layer Chromatography, Gas Chromatography and High-Performance Liquid Chromatography. High-Performance Liquid Chromatography (HPLC) is the most widely used analytical method among these chromatographic methods. [11]. It has wide applications in many fields such as chemistry, biology, genetics, food processing, medical and medicine [12]. HPLC is divided into subheadings such as Normal Phase Chromatography (NPC), Size Exclusion Chromatography (SEC), Ion Exchange Chromatography (IEC) and Reverse Phase Chromatography (RPC), which are developed around different separation processes according to their application area. Among these separation processes, Reverse Phase Chromatography is an analytical method that is used effectively to purify, isolate or separate biomolecules. The main reasons for the preference of RPC are the stability of the system, separation in short-time, serial and high efficient analysis and microscale analysis. Columns developed for reverse phase HPLC systems are mostly silicabased commercial columns. The polydisperse structure of the packed materials used in these columns leads to irregular pressure regimes, whereas nonporous structures lead to inefficient protein separations. The chemical and mechanical strength of these columns, which are very low reusability, is also low. [2-4]. Commonly encountered problems in HPLC columns designed up to now; the long analysis period, the difficulty of some analytes to leave the column, and the difficulty of chromatographic separation due to non-specific interactions. [1, 5-9].
In the first part of the study, we have developed reverse phase packing materials for protein separation, which are highly efficient in chemical and mechanical strength and capable of separating protein mixtures in a short time. In this part of the study, it is aimed to test the suitability of polymeric particles with a uniform size and porosity as a column packing material.

\section{MATERIALS AND METHODS}

\subsection{Column Packed Materials Produced for RPC}

The production of polystyrene (PS) particles used as seed latex in the synthesis of poly(vinyl acetate-co-divinylbenzene) [poly(VAc-co-DVB)] and poly(divinylbenzene) [poly(DVB)] column materials, and the synthesis of uniform-porous poly(VAc-co-DVB) and poly (DVB) particles and the characterization of the resulting particles are described in detail in the first part [13].

\subsection{Preparation of RPC Columns}

Poly(vinyl acetate-co-divinylbenzene) [poly(VAcco-DVB)] and poly(divinylbenzene) [poly(DVB)] particles which are designed as column packing material form columns with DVB2 and DVB3 codes respectively. Particles were packed into $100 \mathrm{~mm}$ x $4.6 \mathrm{~mm}$ ID. stainless steel HPLC columns (Schimadzu, Japan) using water as mobile phase at $20 \mathrm{MPa}(200 \mathrm{~atm})$ pressure and room temperature. After the filling process, the column was washed with the mobile phase used in the analyzes for about 1 hour. Figure 1 gives a schematic representation of column filling.

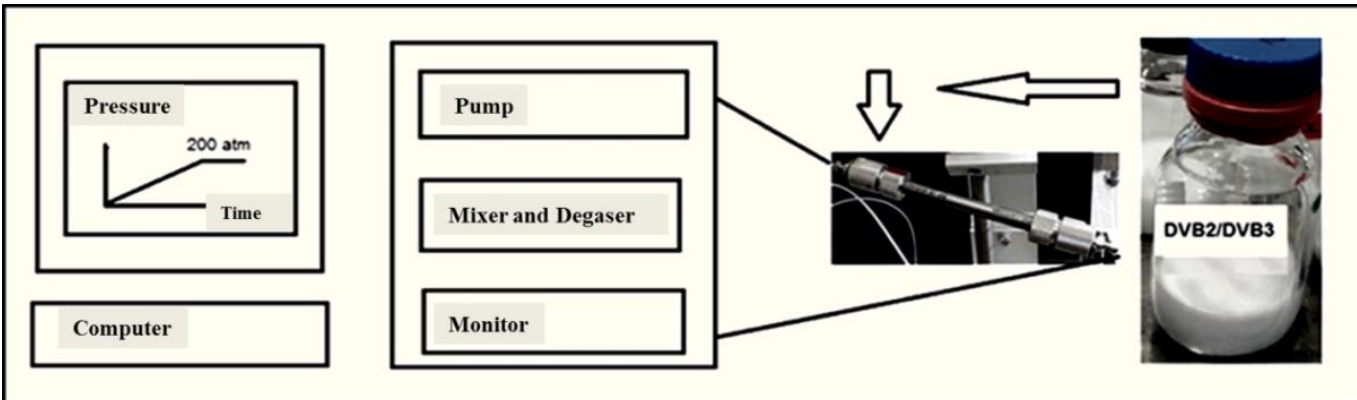

Figure 1. HPLC column filling. 
2.3. Chromatographic Performance of RPC Columns

In this section, Shimadzu Gradient Liquid Chromatograph, LC-10 ADVP and SPD-10 AVVP UV detector were used as HPLC for the chromatographic performance tests. The sample mixture containing 4 different proteins (Sigma) as analytes: Bovine Serum Albumin (BSA, Cat No. A-2153, Fraction V, MA 67,000), Lysozyme (Cat No. L- 6876, MA 14,600), Ribonuclease -A (Cat No: R-5503, MA: 13,700) and Cytochrome-C (Cat No. C-2037, MA: 12,327). As understood from the molecular weights of these proteins, it is aimed that the prepared columns can perform chromatographic separation as wide as possible in the polarity range. In the experiments performed in the RPC mode, different acetonitrile (AcN, purity suitable for HPLC, Aldrich) -water mixtures were used under isocratic conditions as the mobile phase and trifluoroacetic acid (TFA, Aldrich) was added into these mixtures $(0.15 \%$ $\mathrm{v} / \mathrm{v})$.

Experiments on protein separation by RPC in HPLC system were carried out under gradient conditions. Chromatograms were recorded at 280 $\mathrm{nm}$ with a UV-detector. In the chromatographic tests performed for protein separation, a protein mixture containing Ribonuclease A, Cytochrome C, Lysozyme and Bovine Serum Albumin was used. This mixture is a standard mixture which is widely used in the literature to determine the chromatographic performances of Reversed Phase (RP) columns [14-16]. In chromatographic experiments on gradient conditions, the mobile phase gradient was varied between 0.5-2.0 units of $\mathrm{AcN} / \mathrm{min}$. It was used as the mobile phase $\mathrm{A}$ in chromatographic experiments carried out on gradient conditions of AcN containing $5 \%(\mathrm{v} / \mathrm{v})$ water and $0.15 \%(\mathrm{v} / \mathrm{v})$ TFA. Mobile phase B was formed with water and $0.15 \%$ TFA. The gradient was applied linearly at $30 \%$ to $60 \%$ mobile phase A, depending on the column type, on a selected gradient run. This time period was chosen as 30 minutes in the flow rate scan. All chromatographic studies were carried out at room temperature.

\subsection{Determination of Chromatographic Parameters}

The parameters determining the column performances were calculated from the chromatograms obtained in the specified conditions. In each analysis, for all components in the sample mixture injected into the system, variables such as peak width and peak width at half-height were measured, and column performance parameters such as theoretical plate number and peak resolution were calculated, respectively.

The peak resolution for a given protein in the resulting chromatograms is calculated according to Equation [1]. To observe that the two peaks are separated from each other, it is necessary that $\mathrm{R}=$ 1 and this resolution value means that the two bands overlap each other by $2 \%$. If this value is greater than 1.5 , the peaks are completely separated and a good resolution is obtained.

$R_{B / A}=2 \times \frac{\left(t_{B}-t_{A}\right)}{\left(W_{A}+W_{B}\right)}$

[1]

Where: $R(B / A)$ refers to the resolution between the selected peak $B$ and the previous peak $A . t_{B}$ and $t_{A}$ indicate the retention times for peak $B$ and peak $A$, respectively, from the injection point. $W_{B}$ and $\mathrm{W}_{\mathrm{A}}$ represent the peak width for peak $\mathrm{B}$ and peak A, respectively.

Theoretical plate number $(\mathrm{N})$ values were calculated according to Equation [2] using chromatograms obtained in isocratic mode, resulting in chromatographic experiments in which cytochrome $\mathrm{C}$ was used as the analyte.

$\mathrm{N}=5.54 \times\left(t / W_{1 / 2}\right)^{2}$

Where: $\mathrm{t}$ refers to the retention time, $\mathrm{W}_{(1 / 2)}$ is the peak width at half-height. Theoretical plate number increases with column efficiency. 
The protein recovery experiments with the column packed with DVB2 particles were performed under a linear gradient of AcN/water at room temperature with a flow rate $0.75 \mathrm{~mL} / \mathrm{min}$ and a protein concentration of $1 \mathrm{mg} / \mathrm{mL}$. In each run, a single protein was injected into the column. The recovery ratio $(\% \mathrm{w} / \mathrm{w})$ was calculated as the ratio of peak area obtained with the column to that with the same injection performed into the closed loop. In order to obtain run-to-run and day-to-day reproducibities, the analyte mixture containing each protein at a concentration of $1 \mathrm{mg} / \mathrm{mL}$ was injected into the column 10 times/day for one week.

\section{RESULTS AND DISCUSSION}

In the study, the polymeric microspheres in the monodisperse porous structure synthesized in the first part were designed as reverse phase chromatography column packing material with a structure suitable for the proteins to be separated and characterized by Fouirer Transform Infrared Spektrofotometre (FTIR), Scanning Electron Microscopy (SEM) and Brunauer-Emmett-Teller (BET) surface area and porosity measuring device $[13,17]$. The relationship between the back pressure of the HPLC columns obtained with these particles and the mobile phase flow rate was investigated. In subsequent chromatographic analyzes, the effect of these changes on the column separation ability was observed by changing gradient conditions and flow rate.

\subsection{Chromatographic Performance of DVB2 and DVB3 RPC Columns}

The synthesized particles were filled into HPLC columns under high pressure and tested for their suitability in the HPLC system. The behavior of the back pressure flow rate of the columns is shown in Figure 2. As can be seen, the backpressure values obtained with the particles are low compared to the common RPC column materials. It is seen as an advantage because the separation in HPLC columns is carried out in a shorter time at higher flow rates. Compared to the DVB2 column, the rigid pore structure in the
DVB3 column [13] creates a high resistance to flow and this leads to a higher backpressure value.

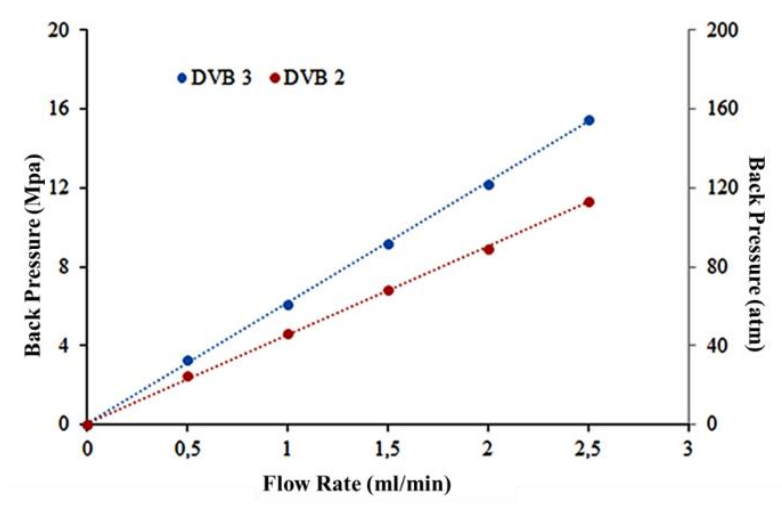

Figure 2. Back pressure-flow rate behavior of RPC columns with DVB2 and DVB3 codes. Mobile phase: AcN/Water Column: 100 x $4.6 \mathrm{~mm}$ ID.

The chromatographic performance of RPC columns encoded as DVB2 and DVB3 were investigated for protein separation under gradient conditions. For this purpose, a mixture of Ribonuclease A, Cytochrome C, Lysozyme and BSA was used. In the first part of the chromatographic studies, the gradient slope was varied in the range of $0.5-2.0$ and the best chromatographic separation was determined for the protein mixture used (Figure 3). In Figure 3, it has been found that both of the columns perform separation, additionally, the DVB2 column performs better than the DVB3 column and the gradient slope is 1.0 unit of $\mathrm{AcN} / \mathrm{min}$, the better the protein peaks are separated. The chromatographic behaviors of the two designed columns are consistent with the results in the literature [14-16]. It appears that each of the proteins in the mixture of proteins given to the column emerged sequentially according to the polarity of the column, and none of them adhered to the column. This result shows that the columns perform the separation. 


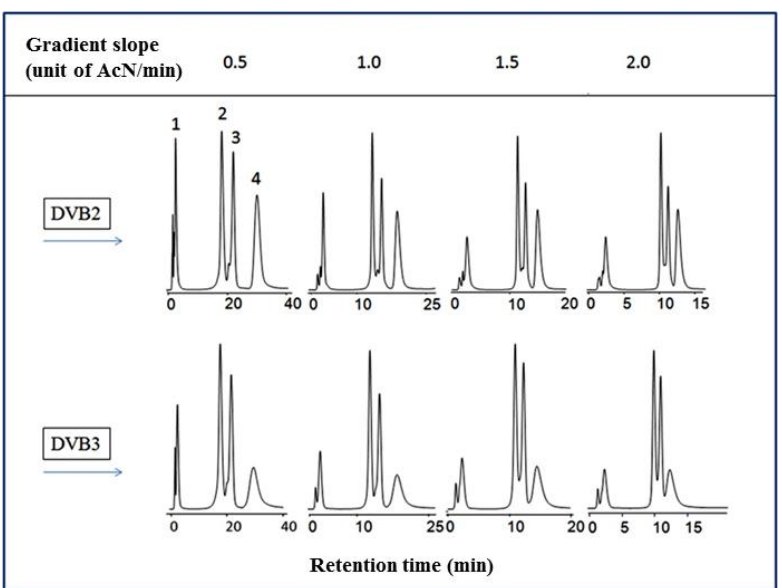

Figure 3. Sample chromatograms showing the effect of gradient slope on protein separation gradient conditions with RPC using DVB2 and DVB3 columns Flow rate ( $\mathrm{mL} / \mathrm{min})$ : $0.75 \mathrm{~mL} / \mathrm{min}$. Mobile phase $\mathrm{A}: \mathrm{AcN}+5 \%$ water $+0.15 \%$ TFA, Mobile phase B: Water $+0.15 \%$ TFA, Gradient conditions: $30 \%$ mobile phase A, $60 \%$ mobile phase B in linear form. Column dimensions: 100x4.6 mm ID., UVdetector $280 \mathrm{~nm}$. Peak order: (1) Ribonuclease A, (2) Cytochrome C, (3) Lysozyme, (4) BSA.

The peak resolution values calculated using the chromatograms obtained at different gradient slopes are given in Table 1. When the slope was 1.0 unit of $\mathrm{AcN} / \mathrm{min}$, resolution values were obtained indicating that the peaks completely separated from each other on the HPLC chromatogram. For this reason, in the next section of the chromatographic studies it was decided to use 1.0 unit $\mathrm{AcN} / \mathrm{min}$ of the gradient slope.

Table 1. Effect of gradient slope on the chromatographic behavior of DVB2 and DVB3 columns. (Flow rate $(\mathrm{mL} /$ min): 0.75 , Mobile phase: $\mathrm{A}: \mathrm{AcN}+5 \%$ water $+0.15 \%$ TFA B: Water $+0.15 \%$ TFA, Gradient conditions: $30 \%$ mobile phase A to $60 \%$ mobile phase B in linear form. Column dimensions: 100x4.6 mm ID).

\begin{tabular}{llll}
\hline Column: DVB2 & & & \\
\hline Gradient slope & $\mathrm{R}(2 / 1)$ & $\mathrm{R}(3 / 2)$ & $\mathrm{R}(4 / 3)$ \\
$\mathbf{0 . 5 0}$ & 11.26 & 2.22 & 3.05 \\
$\mathbf{1 . 0 0}$ & 11.64 & 2.12 & 2.26 \\
$\mathbf{1 . 5 0}$ & 9.60 & 1.80 & 1.84 \\
$\mathbf{2 . 0 0}$ & 10.40 & 1.47 & 1.43 \\
\hline Column: DVB3 & & & \\
\hline Gradient slope & $\mathrm{R}(2 / 1)$ & $\mathrm{R}(3 / 2)$ & $\mathrm{R}(4 / 3)$ \\
$\mathbf{0 . 5 0}$ & 9.06 & 1.86 & 2.07 \\
$\mathbf{1 . 0 0}$ & 9.29 & 1.76 & 1.64 \\
$\mathbf{1 . 5 0}$ & 8.00 & 1.45 & 1.23 \\
$\mathbf{2 . 0 0}$ & 7.41 & 1.27 & 0.92 \\
\hline
\end{tabular}

In the second part, the effect of the mobile phase flow rate on the chromatographic behavior of the columns was investigated. Chromatograms obtained at different flow rates for both columns are given in Figure 4. When these chromatograms are examined, it is seen that column performance is good in the range of flow rate studied.

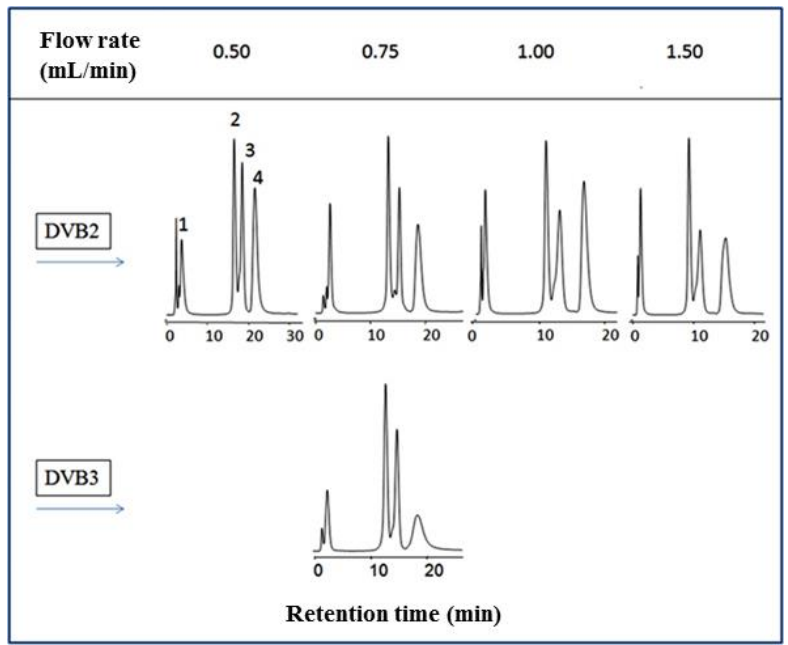

Figure 4. Sample chromatograms showing the effect of mobile phase flow rate on chromatographic separation of DVB2 and DVB3 columns in gradient conditions with RPC Flow rate $(\mathrm{mL} / \mathrm{min}): 0.50,0.75,1.00,1.50$ Mobile phase: A: $\mathrm{AcN}+5 \%$ water $+0.15 \%$ TFA B: Water $+0.15 \%$ TFA, Gradient conditions: $30 \%$ A to $60 \%$ B in 30 minutes in linear form. Column dimensions: 100x4.6 mm ID., UV-detector $280 \mathrm{~nm}$. Peak order: (1) Ribonuclease A, (2) Cytochrome C, (3) Lysozyme, (4) BSA.

As shown in Figure 4, the analysis time in the DVB2 column decreased with the increasing flow rate of the column. At the highest flow rate, the column is able to successfully dissociate all analytes in 14 minutes. In the DVB3 column, the high back-pressure values and the narrow range of the column's operable flow rate are a limiting feature in terms of chromatographic use.

The peak resolution values obtained at different flow rates for the columns are given in Table 2 . Resolution values indicate that the protein mixture can be chromatographically separated at all flow rates. Also, the peak resolution values do not change significantly with flow rate. This means that the analysis time is shortened with increasing flow rate. 
Table 2. Effect of mobile phase flow rate on the chromatographic behavior of DVB2 and DVB3 columns. (Gradient time (min): 30 , Mobile phase: $\mathrm{A} \mathrm{AcN}+5 \%$ water $+0.15 \%$ TFA B: Water $+0.15 \%$ TFA, Gradient conditions: $30 \%$ A to $60 \% \mathrm{~B}$ in linear form Column dimensions : $100 \times 4.6 \mathrm{~mm}$ ID)

\begin{tabular}{cccc}
\hline Column: DVB2 & & & \\
\hline Flow rate (mL/min) & $\mathrm{R}(2 / 1)$ & $\mathrm{R}(3 / 2)$ & $\mathrm{R}(4 / 3)$ \\
$\mathbf{0 . 5 0}$ & 9.77 & 1.58 & 1.87 \\
$\mathbf{0 . 7 5}$ & 11.64 & 2.12 & 2.26 \\
$\mathbf{1 . 0 0}$ & 9.59 & 1.63 & 2.23 \\
$\mathbf{1 . 5 0}$ & 10.85 & 2.31 & 3.14 \\
\hline Column: DVB3 & & & \\
\hline Flow rate (mL/min) & $\mathrm{R}(2 / 1)$ & $\mathrm{R}(3 / 2)$ & $\mathrm{R}(4 / 3)$ \\
$\mathbf{0 . 7 5}$ & 9.26 & 1.76 & 1.64 \\
\hline
\end{tabular}

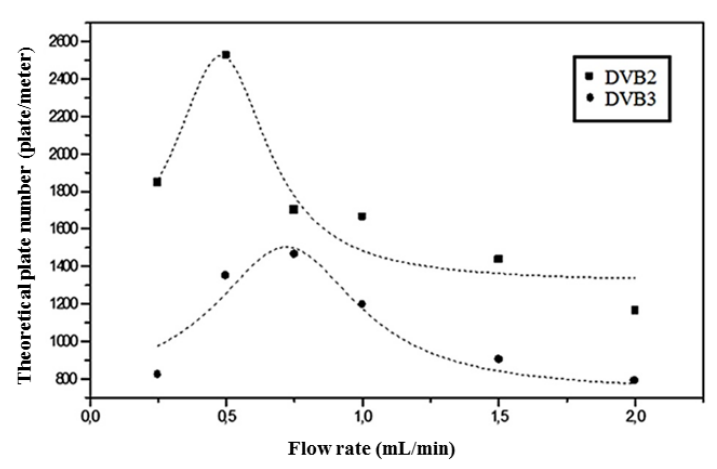

Figure 5. Variation of the theoretical plate number of the DVB2 and DVB3 columns with the flow rate (van Deemter diagram). Mobile phase: A: $\mathrm{AcN} /$ water. Analyte: Cytochrome C (0.25 mg / mL), Column dimensions: 100x4.6 $\mathrm{mm}$ ID., UV-VIS detector, $280 \mathrm{~nm}$.

The relationship between the theoretical plate number indicating the column efficiency and the flow rate is given in Figure 5 for DVB2 and DVB3 columns. As seen here, the highest plate number (highest separation yield) values were obtained with the DVB2 column at a flow rate of $0.5-0.75 \mathrm{~mL} / \mathrm{min}$ between $2000-2600$ plate / $\mathrm{m}$.

The protein recovery values obtained for this column are given in Table 3. Protein recovery is important for repeated use for a column using RPC. If the recovery is low, the analyte supplied to the column is adsorbed by the column material, and regeneration of the column becomes difficult due to the conditioning, which leads to column clogging by increasing the back pressure of the column. Protein recovery of commonly used commercial columns is usually above $90 \%$.
Table 3. Protein recovery values for the DVB2 column. Mobile phase: AcN / water. Protein concentration: $1 \mathrm{mg} / \mathrm{mL}$ (protein solution injected into the column, $10 \mu \mathrm{L}$ ) Flow rate: $0.75 \mathrm{~mL} / \mathrm{min}$.

\begin{tabular}{lc}
\hline Protein & Protein recovery \% \\
\hline Ribonuclease A & 95 \\
Cytochrome C & 99 \\
Lysozyme & 94 \\
BSA & 93 \\
\hline
\end{tabular}

In the last part of the chromatographic studies, the reproducibility tests of the analytes for the DVB2 column were made "run to run" and "day to day". For reproducibility tests, each sample of protein concentration $1 \mathrm{mg} / \mathrm{mL}$ (injection volume, 10 $\square$ L) was injected into the column 10 times a day for one week and the retention times of the analytes were recorded. Relative Standard Deviation (RSD) values of "run to run" and "day to day" values obtained as a result of the analyzes made in the gradient conditions vary between 1.2 $2.8 \%$. These results show that the synthesized column packing material can be used repeatedly for RPC.

\section{CONCLUSIONS}

- Optimum operating conditions for the columns DVB2 and DVB3, respectively, formed with monodisperse and porous apolar poly(VAc-coDVB) and poly(DVB) particles for RPC were $0.75 \mathrm{~mL} / \mathrm{min}$ mobile phase flow rate and 1 unit AcN / min gradient slope has been identified.

- The performance of the DVB2 column in protein separation was observed to be better than the DVB3 column due to its higher resolution and theoretical plate number.

- Protein recovery values for the DVB2 column are quantified for all proteins.

- Analytes for the DVB2 column were tested for reproducibility and Relative Standard Deviation (RSD) values were found in the range of $1.2-2.8 \%$. These results show that the synthesized column material can be successfully used for RPC. 
- The DVB2 column synthesized in the study was exhibited a chromatographic performance similar to the columns used commercially for protein separation in gradient conditions. In addition, the high chemical and mechanical strength, protein recovery, theoretical plate number, reproducibility and low back pressure of DVB2 column packing materials are superior to commercial columns.

\section{REFERENCES}

[1]. Caml, S.T., Şenel, S., Tuncel, A., Cibacron Blue F3G-A Attached Uniform and Macroporous Poly(styrene-divinlybenzene) Particles For Specific Albumin Adsorption. J. Biomater. Sci. Polym., 8 (1999) 875-889.

[2]. Ellingsten, T., Aune, O., Ugelstad, J., Hagen, S., Mono-sized Stationary Phases for Chromatography, Journal of Chromatography A, 535 (1990) 147-161.

[3]. Galia, M., Svec, F. , Fréchet, J.M.J., Monodisperse Polymer Beads as Packing Material for High-performance Liquid Chromatography. Effect of Divinylbenzene Content on the Porous and Chromatographic Properties of Poly(styrene-co-divinylbenzene) Beads Prepared in Presence of Linear Polystyrene as a Porogen, J. Polym. Sci., Polym. Chem., 32 (1994) 2169-2175

[4]. Hossoya, K., Teramachi, M., Tanaka, N., Kobayashi, A., Kanda, T., Ohtsu, Y., Preparation Strategy for Uniformly Sized, Polymer-Beads HPLC Packing Materials Having Practically Acceptable Column Efficiency. 1. Copolymerization Technique, Anal. Chem., 73(24) (2001) 5852-5857

[5]. Lewandowski, K., Svec, F., Frechet, J.M.J., Polar, A Novel Polar Seperation Medium For The Size Exclusion Chromatography of Small Molecules: Uniformly Sized, Porous Poly(vinylphenol-co-divinylbenzene) Beads, J. Liq. Chrom. \& Rel. Technol., 20 (1997) 227-243

[6]. Smigol, V., Svec, F., Frechet, J.M.J., 2Dimensional High-Performance LiquidChromatography Using Monodisperse Polymer Beads Containing Segregated
Chemistries Prepared By Pore-Size Specific Functionalization - $\quad$ Single-Column Combinations of Size Exclusion Or İonExchange With Reversed-Phase Chromatography, Analytical Chemistry, 66 (23) (1994) 4308- 4315

[7]. Smigol, V., Svec, F., Frechet, J.M.J., HighPerformance Liquid Chromatography of Complex mixtures Using Monodisperse DualChemistry Polymer Beads Prepared by a PoreSize-Specific Functionalization Process. A Single Column Combination of Hydrophobic Interaction and Reversed-Phase Chromatography, Analytical Chemistry, 66 (13) (1994) 2129-2138

[8]. Unsal, E., Durdu, A., Elmas, B., Tuncel, M., Tuncel, A., A New Affinity-HPLC Packing For Protein Separation: Cibacron Blue Attached Uniform-Porous Poly(HEMA-coEDM) Beads, Analytical and Bioanalytical Chemistry, 383 (2005) 930-937

[9]. Unsal, E., Irmak, T., Durusoy, E., Tuncel, M., Tuncel, A., Monodisperse porous particles with polyionic ligands for ion exchange separation of proteins, Analytical Chimica Acta, 570 (2006) 240-248

[10].Ettre, L.S., Chromatography: the Separation Technique of the 20th Century. Chromatographia, 51 (1/2) (2000) 7-17

[11]. Engelhardt, H., One century of liquid chromatography from Tswett's columns to modern high speed and high performance separations, Journal of Chromatography B, 800 (1-2) (2004) 3-6

[12].Zhang, Y. W., Yao, S., Zeng, H., Song, H., Chiral Separation of Pharmaceuticals by High Performance Liquid Chromatography, Current Pharmaceutical Analysis, 6 (2) (2010) 114-130

[13]. Saraçoğlu Kaya, B., Sağ, E., Design of Reversed Phase Chromatography (RPC) Column Packing Material for Protein Separation: Part 1- Synthesis and Characterization, Cumhuriyet Science Journal, 38 (4) (2017) 788-797

[14]. Unsal, E., Camli, S. T., Irmak, T., Tuncel, M., Tuncel, A., Monodisperse poly(styreneco-divinylbenzene) particles $(3.2 \mu \mathrm{m})$ with 
relatively small pore size as HPLC packing material, Chromatographia, 60 (2004) 553560

[15]. Unsal, E., Camli, S.T., Senel, S., Tuncel, A., Chromatographic Performance of Monodisperse-Macroporous Particles Produced by "Modified Seeded Polymerization." I: Effect of Monomer/Seed Latex Ratio, Journal of Applied Polymer Science, 92 (2004) 607-618

[16]. Unsal, E., Elmas B., Camli, S.T., Senel, S., Tuncel, A., A Uniform Particles For The
Reversed Phase Separation of Proteins With High Resolution and High Column Efficiency, Separation Science and Technology, 40 (2005) 1425-1438

[17]. Çağlayan, B., Unsal, E., Çamlı, T., Tuncel, M., Tuncel, A., Monodisperse Porous Poly(Vinyl Acetate-Codivinylbenzene) Particles By Single-Stage Seeded Polymerization: A Packing Material For Reversed Phase HPLC. J. Sep. Sci., 29 (2006) 936 - 944 